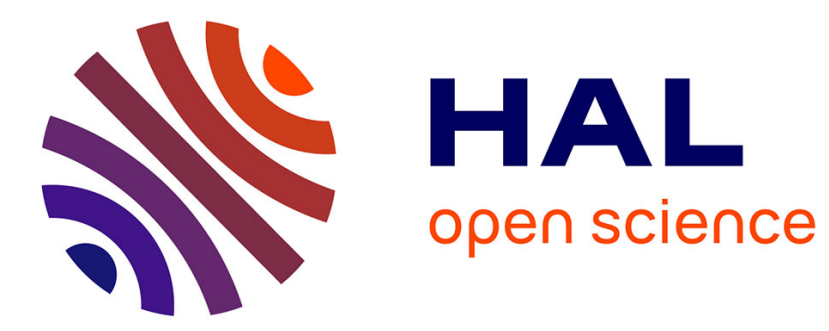

\title{
Food without sun: Price and life-saving potential
}

David C Denkenberger, Ray A Taylor, Ryan A Black, Joshua Pearce

\section{To cite this version:}

David C Denkenberger, Ray A Taylor, Ryan A Black, Joshua Pearce. Food without sun: Price and life-saving potential. Foresight, 2018. hal-02111364

\section{HAL Id: hal-02111364 \\ https://hal.science/hal-02111364}

Submitted on 26 Apr 2019

HAL is a multi-disciplinary open access archive for the deposit and dissemination of scientific research documents, whether they are published or not. The documents may come from teaching and research institutions in France or abroad, or from public or private research centers.
L'archive ouverte pluridisciplinaire HAL, est destinée au dépôt et à la diffusion de documents scientifiques de niveau recherche, publiés ou non, émanant des établissements d'enseignement et de recherche français ou étrangers, des laboratoires publics ou privés. 


\title{
Food without sun: Price and life-saving potential
}

Foresight, 2018

David C. Denkenberger, ${ }^{1,2,3}$ Ray A. Taylor,${ }^{3}$ Ryan A. Black,,${ }^{1}$ Joshua M. Pearce ${ }^{4}$

${ }^{1}$ Tennessee State University, 3500 John A Merritt Boulevard; Nashville, TN 37209, USA. Email: ddenkenb@tnstate.edu; Phone: +1-615-963-5419; ORCID: 0000-0002-6773-6405

${ }^{2}$ Global Catastrophic Risk Institute, USA. E-mail: david.denkenberger@gmail.com

${ }^{3}$ Alliance to Feed the Earth in Disasters (ALLFED), US, UK.

${ }^{4}$ Michigan Technological University, Houghton, Michigan, USA.

Keywords: nuclear war; global catastrophic risk; existential risk; economics; food; Article Classification: Research Paper

\begin{abstract}
:
The sun could be blocked by an asteroid impact, supervolcanic eruption, or nuclear winter caused by burning of cities during nuclear war. The primary problem in these scenarios is loss of food production. Previous work has shown that alternate foods not dependent on sunlight, such as bacteria grown on natural gas, calories extracted from killed leaves, and cellulose turned into sugar enzymatically, could feed everyone in these catastrophes and preparation for these foods would save lives highly cost-effectively. This study estimates the price of alternate foods during a catastrophe scenario with global trade and information sharing, but no migration, loans, aid or conflict. Without alternate foods, for a five year winter, only $~ 10 \%$ of the population would survive. The price of dry food would rise to $\sim \$ 100 / \mathrm{kg}$, and the expenditure on this food would be $\sim \$ 100$ trillion over five years. If alternate food were $\$ 8 / \mathrm{kg}$, the surviving global population increases to $\sim 70 \%$, saving $>4$ billion lives. The probability of a loss of civilization and its impact on many future generations would be much lower in this scenario and the total expenditure on food would be halved. Preparation for alternate foods would be a good investment even for wealthy people who would survive without alternate foods. A nongovernmental mechanism of coordinating the investments of these rich people may be possible. Identifying companies whose interests align with alternate food preparations may save lives at a negative cost.
\end{abstract}

\section{Introduction}

A number of catastrophes could obscure the sun, including bolide (asteroid/comet) impact, supervolcanic eruption, and nuclear war with the burning of cities creating nuclear winter (Bostrom and Cirkovic, 2008). Though the direct mortality from these catastrophes could be in the hundreds of millions of people, the resultant blocking of the sun would result in the collapse of conventional agriculture and would cause billions of deaths despite stored food. Collapse of civilization is likely, and one definition of this collapse involves loss of government, short-term focus, collapse of long distance trade, and widespread conflict (Coates, 2009). Recovery of civilization is not guaranteed, and human extinction could result eventually (Maher and Baum, 2013). When considering human extinction, many more future lives would be lost than just the present generation (Bostrom, 2003). However, recent research has shown that 
"alternative foods" not dependent on sunlight could provide a new source of calories for the world's population (Denkenberger and Pearce, 2015). In such catastrophes, most of industrial infrastructure would be intact. Although, it is possible that the breakdown of international cooperation or a further (subsequent) catastrophe would cause industry to fail (Denkenberger and Pearce, 2017). In this study, the scenario of industry continuing to function is considered, which allows industrially-related alternate foods including natural gas digesting bacteria (Unibio, 2014) and cellulose transformed into sugar (Humbird et al., 2011) on a large scale. Other foods include ruminants (cows, sheep, and goats) and rabbits fed by dead leaves. Mushrooms can grow on dead trees, and the waste from this can be fed to ruminants and rabbits (Spinosa, 2008). Bacteria can grow on dead leaves and the partially decomposed leaves can be fed to insects, rats and possibly even chickens. Chickens could also eat food wasted by humans. Freshly killed leaves can have edible calories extracted for humans (Kennedy and Leaf for Life, 1993). In cases where the sun is not completely blocked, the ozone layer would be disrupted, possibly causing high ultraviolet radiation. Still, the ocean absorbs significant ultraviolet radiation. Also, the cooling of the ocean would cause upper layers to sink, bringing nutrient rich water to the surface. This may actually allow increased algae growth in the ocean and produce a significant amount of fish. Plants that are resistant to ultraviolet radiation and cold could grow in the tropics. These could come from high-altitude areas, such as Tibet, but this would take time to scale up the food supply (Denkenberger et al., 2017). Together, these alternate foods could more than feed everyone (Denkenberger and Pearce, 2014). Though production of these foods could technically be scaled up without preparation, preparation makes the success more likely. The cost of research, development, and planning would be very low, and therefore presents a cost-effective way of saving expected lives assuming that the alternate foods would be affordable (Denkenberger and Pearce, 2016). This means that this preparation makes sense for organizations/individuals who value saving lives, such as United Nations affiliates, international aid and development government programs, nongovernmental organizations performing international aid and development, and government programs targeted only at their own citizens.

This study seeks to estimate the price of alternative foods during an agricultural catastrophe and determine the percent of the global population that would be able to afford enough food to prevent starvation. It also estimates expenditure on food, which can make the case for purely monetary investments in alternate foods preparations.

\section{Current Price of Alternate Foods}

A number of alternate foods for humans and feeds for animals are already commercially available. In some cases, the commercially available food is not exactly the same in terms of species or feed source, but can be used as reasonable estimates of baseline price. Of course, food prices could change dramatically during a catastrophe. Some reasons for higher food prices following a catastrophe include: 1) requirement for rapid scale up, 2) specially built infrastructure being utilized for a shorter period of time (only during the catastrophe), 3) less experienced labor, 4) possible higher priced labor and 5) higher utility (e.g. energy) prices. However, there are reasons for lower food prices during a catastrophe than in normal times, including: 1) more economies of scale for alternate foods, 2) more learning from producing more cumulative quantity 3) utilizing infrastructure idled by the economic recession/depression caused 
by the catastrophe, 4) possible lower prices of labor due to high unemployment, and 5) possible utility price decreases (e.g. if demand for an input falls during the catastrophe).

Even considering these complexities, current prices shed some light on what catastrophic prices for alternative foods may be. In order to determine these prices first the energy density $(\mathrm{kcal} / \mathrm{kg}$ ) of foods and the price of foods (USD/kg) is found currently. Where only wholesale prices could be found, retail prices are determined by multiplying wholesale price by 2.0 found by averaging the markup of five foods (USDA, 2017a). The prices are adjusted for recent global inflation of 3.3\% per year (Yardeni et al., 2017). All values are adjusted to bone dry carbohydrate (hereafter referred to as "dry") following (Denkenberger and Pearce, 2015).

Some bacteria can use methane as an energy and carbon source to produce fish food (Unibio, 2014). Since recent natural gas price in the U.S. has been $\$ 5$ per billion joules (GJ) ("United States Natural Gas Industrial Price", 2017) and if the caloric conversion efficiency is $31 \%$ (half of the ideal (Roslev et al., 1997)), the energy cost of the methane digesting bacteria would be $\$ 0.27 / \mathrm{kg}$ dry. If the other costs of equipment, etc. double the price, then adjusting to retail yields $\$ 1.1 / \mathrm{kg}$ dry (see Table 1 ).

Table 1. Current alternate food retail prices and income required to afford these foods.

\begin{tabular}{|c|c|c|c|}
\hline Alternate Food & $\begin{array}{l}\text { Price } \\
\text { (\$/dry kg) }\end{array}$ & $\begin{array}{l}\text { Per person income } \\
\text { required to afford } \\
(\$ / \text { day })\end{array}$ & $\begin{array}{l}\text { Per person income } \\
\text { required to afford } \\
(\$ / \text { year })\end{array}$ \\
\hline Methane digesting bacteria & 1.1 & 0.6 & 200 \\
\hline Cellulosic glucose & 2 & 1.0 & 400 \\
\hline Sardine & 3 & 1.3 & 500 \\
\hline Tibetan wheat & 3 & 1.4 & 500 \\
\hline Leaf extract & 5 & 3 & 1,000 \\
\hline Cow Milk & 6 & 3 & 1,100 \\
\hline Chicken Eggs & 6 & 3 & 1,100 \\
\hline Chicken Meat & 11 & 6 & 2,000 \\
\hline Meal Worm (larva) & 18 & 10 & 3,000 \\
\hline Beef & 30 & 16 & 6,000 \\
\hline White Button Mushroom & 70 & 40 & 15,000 \\
\hline Artificial light algae & 110 & 60 & 20,000 \\
\hline Artificial light vegetables & 600 & 300 & 110,000 \\
\hline
\end{tabular}

Leaves/agricultural residue are largely composed of hemicellulose, cellulose, and lignin. These can be turned into food with a number of methods including chemical processing, mushrooms, and the use of ruminants.

On the chemical side, pretreatment processes (such as dilute acid) can break hemicellulose into sugars that are still generally inedible to humans. However, they can be fed to cellulose-digesting animals and can also be fermented into ethanol. This latter use would displace the current use of human edible food to produce ethanol. This ethanol is produced by bacterial fermentation, and the bacteria can tolerate significant contamination. Therefore, the price of this sugar is approximately $\$ 0.31 / \mathrm{kg}$ (Humbird et al., 2011). To use these hemicellulose sugars for animal feed would require further purification. It would likely be similar in price to 
the glucose that comes from breaking down cellulose, which is about $\$ 0.81 / \mathrm{kg}$ (Humbird et al., 2011). Adjusting the glucose (which humans can eat) price to 2017 and retail yields $\$ 2 / \mathrm{kg}$ dry (see Table 1).

Wheat flour has $3640 \mathrm{kcal} / \mathrm{kg}$ (USDA, 2016), and had a price of $\$ 1.15 / \mathrm{kg}$ retail in 2015 (USDA, 2015). The Tibetan plateau is harsh growing conditions including short growing season, low carbon dioxide concentration, and high ultraviolet radiation. Therefore, the price is adjusted upward by $100 \%$. Adjusting to 2017 yields $\$ 3 / \mathrm{kg}$ dry (see Table 1).

There is great variety in fish prices. However, in this study, sardines are used as a base case because these small fish can grow in population quickly (Smith, 1985). The wholesale price of wet sardine is $\$ 0.65$ per kg ("Wholesale Sardines", n.d.). Sardines are $2080 \mathrm{kcal} / \mathrm{kg}$ (USDA, $2017 \mathrm{~b}$ ), which corresponds to $\$ 3 / \mathrm{kg}$ dry (see Table 1).

Human food has been produced from leaves both on the household (Kennedy and Leaf for Life, 1993) and industrial scale (Leaf for Life, 2013). The process involves grinding the leaves, removing the solids, and heating the remaining liquid. Part of the material coagulates and is removed as human food (leaf extract), and there are calories in the remaining brown liquid. Watering pigs with this brown liquid causes kidney problems over time, but it may be possible to feed it to broiler chickens because they are slaughtered at an early age. The backup plan is feeding the brown liquid to cellulose digesters. Leaf extract price was $\$ 0.46 / \mathrm{kg}$ wet wholesale in 1993 (Kennedy and Leaf for Life, 1993) which is adjusted to \$5/kg dry retail in 2017 (see Table 1). It should be noted that the age of the studies on leaf extract caused the current price to be dominated by inflation. However, a similar price of $\$ 6 / \mathrm{kg}$ dry retail was found for the industrial leaf concentrate process in 2017 (OPEF, 2017).

The wholesale price of cow milk is $\$ 0.30$ per $\mathrm{kg}$ (Warren, 2017) and milk is $602 \mathrm{kcal} / \mathrm{kg}$ (United States Department of Agriculture, 2006). The wholesale price of wet beef is $\$ 7.23 \mathrm{per} \mathrm{kg}$ (Hahn, 2017) and beef is $1980 \mathrm{kcal} / \mathrm{kg}$ (United States Department of Agriculture, 2006). These correspond to $\$ 6$ and \$26/kg dry for milk and beef, respectively in 2017 (see Table 1).

The wholesale price of wet chicken eggs is $\$ 0.89$ per $\mathrm{kg}$ (USDA, 2017c) and eggs are $1430 \mathrm{kcal} / \mathrm{kg}$ (United States Department of Agriculture, 2006). Wet chicken meat is $\$ 2.27 \mathrm{per} \mathrm{kg}$ wholesale (USDA, 2017d) and chicken is $1190 \mathrm{kcal} / \mathrm{kg}$ (United States Department of Agriculture, 2006). These correspond to $\$ 6$ and $\$ 11 / \mathrm{kg}$ dry for eggs and chicken, respectively in 2017 (see Table 1).

Some insects are made for human consumption. However, they are very expensive because of lack of economies of scale. More representative would be insects used as animal feed, such as mealworm larvae. The wholesale price is approximately $\$ 5 / \mathrm{kg}$ ("Wholesale Mealworm Larvae", n.d.). These insects are $2060 \mathrm{kcal} / \mathrm{kg}$ (Kouřimská and Adámková, 2016). This corresponds to $\$ 18 / \mathrm{kg}$ dry retail in 2017 (see Table 1).

The wholesale price of white button mushrooms is $\$ 1.48$ per $\mathrm{kg}$ wet (USDA, 2017e). These mushrooms are $170 \mathrm{kcal} / \mathrm{kg}$ (United States Department of Agriculture, 2006). This corresponds to $\$ 67 / \mathrm{kg}$ dry in 2017 (see Table 1).

The conversion efficiency of electricity to visible light is $\sim 30 \%$ for fluorescent fixtures (a fluorescent fixture is $\sim 65$ lumens/W (Myer et al., 2009), and white light at 100\% electrical efficiency is $\sim 220$ lumens/W). The ideal efficiency is $9 \%$ for microalgae grown in solar bioreactors, but $3 \%$ is more realistic (Wijffels and Barbosa, 2010). Because algae has inherently higher photosynthetic conversion and because vegetables have to grow significant inedible above and below ground mass, vegetable photosynthetic conversion is estimated to be $0.3 \%$. Solar energy is only $50 \%$ visible (roughly what plants convert), so the efficiency of plants with 
artificial light would be correspondingly higher. It is assumed that the fact that plants utilize lower intensity light more efficiently counteracts the fact that the algae/food would not be $100 \%$ digestible. Therefore, the electrical to food energy efficiency would be $\sim 0.2 \%$ for algae and $0.02 \%$ for vegetables. At $\$ 0.10 / \mathrm{kWh}$, a conservatively low estimate of electric rates, this yields $\$ 30$ and $\$ 300 / \mathrm{kg}$ dry for algae and vegetables, respectively. It is estimated that the ancillary equipment for algae production doubles the wholesale price, and then the standard factor of two markup to retail is applied. However, with the extreme price of vegetables, only a factor of 1.5 is used to multiply the cost for ancillary equipment and 1.5 for retailing. This yields $\$ 110$ and $\$ 600 / \mathrm{kg}$ dry for algae and vegetables, respectively (see Table 1).

One alternate food suggested in the literature that is not considered here is humans consuming partially decomposed leaves. This is because this has not been commercially demonstrated and it is not an appealing food. Also not considered are rabbits and rats. Further omitted is feeding manure to animals. All of which is left to future work because of the relative non-desirability.

There is uncertainty in how the current prices will change during a catastrophe. However, it is reasonable to prioritize those food sources that currently have a low price. Though the price of mushrooms currently is high, it may be that certain feedstocks will still have a low price in a catastrophe. Then if the dollar-a-day poor had access to this feedstock and some training, since the labor required would be reasonable, they should be able to feed themselves. If their wage remained constant, this would necessarily be at food price less than $\$ 2 / \mathrm{kg}$. However, this requires future work to prove. Therefore, the most promising alternate foods are the ones that are lower price now, namely methane-digesting bacteria, cellulosic sugar, Tibetan wheat, and sardines. As can be seen in Table 1, these four foods can be afforded with a per person income of $\$ 1.4 /$ day or less.

\section{Surviving Population and Food Expenditure with Different Food Prices}

There are many different possible scenarios for cooperation if the sun is blocked, some of which are listed here. The most favorable is the technical feasibility, which assumes trade, aid, loans, information sharing and migration. This has been explored in previous work (Denkenberger and Pearce, 2014). The second most favorable scenario could be called "free market functioning," where there is global trade, migration, information sharing and loans. One advantage of this scenario for modeling purposes is that there would be global food prices and global resources could still be exploited through trade. Then there are two scenarios that are not as favorable. One is breakdown of global trade, aid, loans, information sharing and migration, but no war: every country for themselves. This would require much country-specific data. Then there is partial breakdown of international cooperation with war between some countries, but alliances between others. This would also need much country-specific data, and deciding on the conflicts/alliances would make it much more difficult to model reliably. Finally, the least favorable scenario would be breakdown of cooperation even within countries, possibly resulting in vandalism, gangs and murder. This could result in the destruction of biomass and infrastructure and be every person or gang for themselves. This is also difficult to model.

In reality, the probability of each of these scenarios depends partially on the price and availability of food. For the purposes of this paper, a scenario of global trade and information 
sharing is analyzed without migration, loans, aid or conflict. In this scenario, whether people survive depends entirely on their ability to afford the food.

If food price remains relatively low, there would be limited disruption of society. Alternate foods could be produced with a relatively low labor (e.g. the use of tree harvesters or chainsaws instead of hand saws) (Denkenberger and Pearce, 2015). However, the same could be said for agriculture now, and yet many farmers still use very labor-intensive methods (the global majority). Therefore, it is reasonable that if the sun were blocked, people in current less developed countries would use labor-intensive techniques to produce alternate foods. It is therefore even possible that wages will increase as the people are producing more valuable food. Of course it is also possible that wages decrease. This may be more likely for cases of high food price and mass starvation because there would be significant disruption of society. As a first estimate, the middle scenario of current incomes is used here.

An important question is whether people could use their wealth (net worth) to purchase more food. This would mainly be relevant for the high food price scenarios (including only stored food) because it is generally the higher income people who have significant wealth. The scenario considered is one where institutions such as stock markets still function. There may be large changes in net worth, including loss of stocks and bonds in companies that go out of business. There could also be large increases in net worth for people who own a significant amount of stored food (perhaps through owning stocks in companies that own significant amounts of stored food). Despite these large shifts in net worth, there would still likely be a significant amount of positive net worth. Using this net worth to purchase food would make stored food even more expensive, which would make alternate food look more favorable. Therefore, this is conservatively ignored here. Table 2 shows income distribution from 2011 up to $\$ 66$ per day (Kochhar, 2015) inflated at 3.3\% and using $1.5 \%$ economic growth (Bank, 2017) for all income brackets. In reality, different income brackets have grown at very different rates recently (Milanovic, n.d.), so this is a first approximation. The income data are purchasing power parity (the ability to buy local goods and services). This could be appropriate if much of the food is produced locally. In reality, much food would be shipped globally, so again this is approximate.

Table 2. Income ranges, population, food price afforded, and for the case of only storage for each income bracket, fraction of food requirement, years survive, total food consumption and population that survives (food price is $\$ 96 / \mathrm{kg}$ dry).

\begin{tabular}{|c|c|c|c|c|c|c|}
\hline $\begin{array}{l}\text { Purchasing } \\
\text { power parity } \\
\text { income (\$/day) } \\
\text { lower bound bin } \\
\text { inflated and } \\
\text { grown to } 2017\end{array}$ & $\begin{array}{l}\text { Population } \\
\text { (billion) }\end{array}$ & $\begin{array}{l}\text { Lower } \\
\text { bound of } \\
\text { the bin } \\
\text { can } \\
\text { afford } \\
(\$ / \mathrm{kg})\end{array}$ & $\begin{array}{l}\text { Food } \\
\text { consumption } \\
\text { (fraction of } \\
\text { requirement) }\end{array}$ & $\begin{array}{l}\text { Years } \\
\text { survive }\end{array}$ & $\begin{array}{l}\text { Food } \\
\text { consumed } \\
\text { (Gt over } 5 \\
\text { yr) }\end{array}$ & $\begin{array}{l}\text { Population } \\
\text { that } \\
\text { survives } \\
\text { (billion) }\end{array}$ \\
\hline 0 & 0.21 & 0.00 & 0.013 & 0.25 & 0.00013 & 0 \\
\hline 1.3 & 2.1 & 2.5 & 0.053 & 0.26 & 0.0056 & 0 \\
\hline 4.0 & 3.0 & 8 & 0.17 & 0.30 & 0.029 & 0 \\
\hline 13 & 1.2 & 25 & 0.53 & 0.53 & 0.065 & 0 \\
\hline 40 & 0.22 & 76 & 0.92 & 3.13 & 0.12 & 0 \\
\hline
\end{tabular}




\begin{tabular}{|r|r|r|r|r|r|r|r|}
\hline 53 & 0.15 & 100 & 1.000 & 5.00 & 0.15 & 0.15 \\
\hline Totals & 0.61 & 130 & 1.000 & 5.00 & 0.58 & 0.61 \\
\hline
\end{tabular}

The most likely cause of the sun being blocked is nuclear winter and work should be done to reduce this as much as possible (Shultz et al., 2007). The impacts of nuclear winter would last a decade or more (Robock et al., 2007). However, shown below, a small fraction of people will survive on stored food only. Therefore, agriculture does not need to fully recover in order to support the remaining people, so it is estimated that stored food would have to last five years. The annual average global wheat storage is 4 months at current wheat consumption (Do et al., 2010). Grain production is 2.7 billion tons (Gt) per year (Tilman et al., 2002), and grains are $\sim 29 \%$ total of fiber and moisture (Hurburgh, 2006; United States Department of Agriculture, 2006). Since carbohydrate contains $4 \mathrm{kcal} / \mathrm{g}$, this is $\sim 1.9 \mathrm{Gt} / \mathrm{yr}$ dry carbohydrate equivalent. Grains make up roughly half of the calories produced (Meadows et al., 2004); therefore, the total food production is $\sim 3.8 \mathrm{Gt}$ dry/yr. Dry bulk grains are significantly less expensive to store than other foods, so it is expected that grains make up the majority of storage. If there are four months storage at current production rate of all grains, this is $0.6 \mathrm{Gt}$ dry. In addition, it is estimated that households, stores, warehouses and livestock increase the total food storage by $50 \%$, meaning approximately $1 \mathrm{Gt}$ dry. In reality, the catastrophes are likely to kill a significant number of people and burn or radioactively contaminate some stored food. However, if the percentage of these is similar, the survival percentage on stored food would be similar. Therefore, the current food storage and current population are used, but survival is generally expressed as percentages.

If there is only stored food, food prices will rise very high, and many people will be barely able to afford the food needed to survive. These people would be nearly vegan, as the extreme poor of the world are today. There are many people much richer that will still be able to afford eating more normally from the expensive stored food. Therefore, in this scenario of no charity, there will still be significant animal product consumption. Some of the stored food will be animal products (which could be preserved quickly if fresh), and the current standing livestock will provide significant meat. Waste will be minimal because of the high price. The recommended consumption is $2,100 \mathrm{kcal} /$ day is used here (Kummu et al., 2012), though it is possible to consume fewer than 2,100 kcal per day, so it is assumed that waste accounts for this difference. This also means that people purchase slightly less than 2,100 kcal per day (because some waste occurs in distribution). But if 2,100 kcal per day purchases are assumed for the income requirement, this difference allows consumption of other necessities. Currently a significant amount of food goes to biofuels and pets. In a stored food only scenario, the population will be much smaller, so petroleum will be more than sufficient, so no food would need to be used to produce biofuels. Pets could still be afforded by the very rich. However, there would likely be some production of food from artificial light, and some from fishing if the sun is not completely blocked. Therefore, it is estimated that these factors would counteract and it would work out to negligible stored food fed to animals. 2,100 kcal/day of dry carbohydrate is $520 \mathrm{~g} / \mathrm{day}$, and this would correspond to approximately 1.0 billion people surviving for five years on the stored food or $13 \%$ of the initial population.

However, this is the optimal case scenario for survival population where no food is consumed by people who will eventually starve to death. More realistically, some of the food will be consumed by people who will not survive. It is estimated that people could survive for three months with no food. People who cannot afford sufficient food will consume a fraction of 
the requirement, prolonging their life. For each income range, the food consumption and whether that bracket survives or not is tracked (see Table 2). Survival is based on the average income of the bracket, which is an approximation. In the stored food only case, the results show that only $10 \%$ of people could survive for five years as shown in Figure 1. Figure 1 also shows the total expenditure on food during the catastrophe. This corresponds to a food price of $\$ 96 / \mathrm{kg}$, which is an overall expenditure on food of $\$ 91$ trillion. Expenditure is based on current stored food amount.

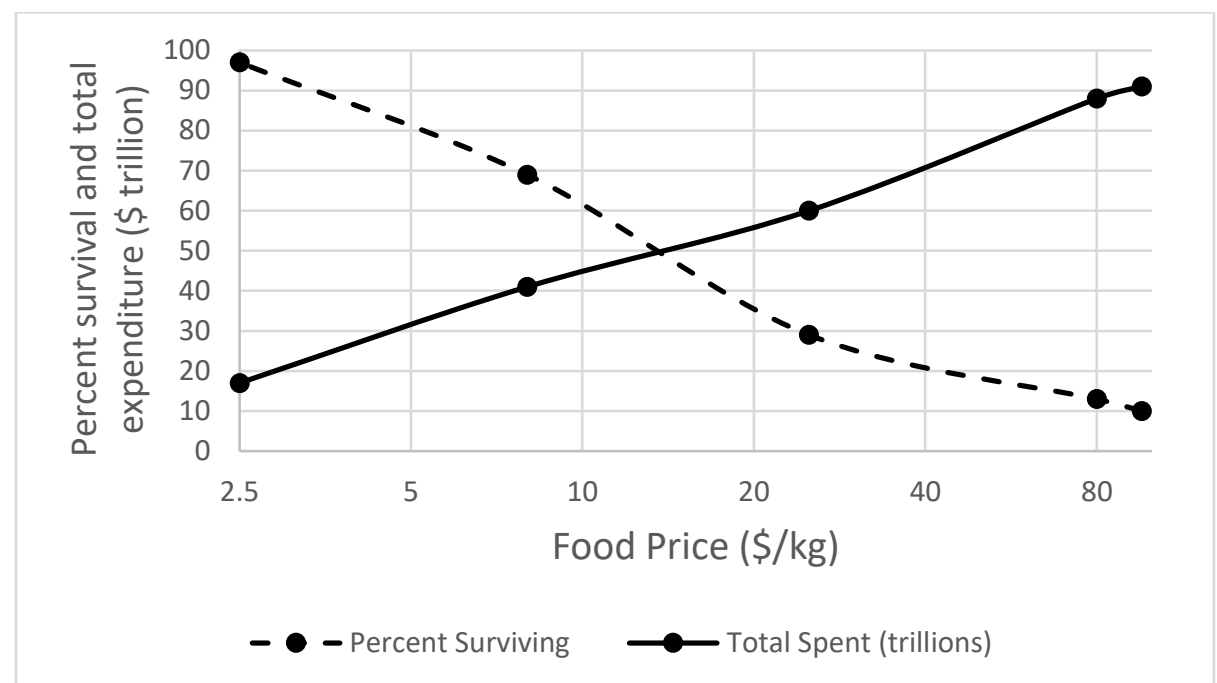

Figure 1. Survival percentage and total catastrophe food expenditure ( $\$$ trillion) as a function of food price $(\$ 96 / \mathrm{kg}$ is stored food only).

With alternate foods, the supply is no longer limited. However, the price might be still be relatively high. The current prices of alternate foods give some indication of that future price. Richer people would tend to eat the more desirable alternate and stored foods. In order to provide adequate nutrition without supplements/fortification, a variety of alternate foods would be required (Griswold et al., 2016). Given the high price of some alternate foods currently, supplements/fortification would likely be less expensive than a varied diet. The food price in the model used here corresponds to the low price types of food as those would determine survival, even though other foods on the market could be considerably higher priced. A sensitivity of $\$ 2.50 / \mathrm{kg}$ to $\$ 80 / \mathrm{kg}$ for the lower end of the food price spectrum is calculated and the results are shown in Figure 1.

At a price of $\$ 2.50 / \mathrm{kg}$, nearly everyone would survive (97\%). This could be possible with cellulosic sugar and methane-digesting bacteria. Another possibility would be storing up massive amounts of seeds that could grow better in cold and UV than current Tibetan varieties. This should lower the catastrophe price, but present-day storage costs would make this option less appealing. A further possibility would be genetically engineering spore-producing crops (spores are like seeds, but much smaller, so plants could increase in number much faster, requiring fewer plants or spores to start with). This could be accomplished by modifying a crop to produce spores or modifying a spore-producing plant to become a useful crop. Regardless of how this low alternate food price is achieved, with the assumption of low waste, this corresponds to a total expenditure on food during the catastrophe of $\$ 17$ trillion. Though the assumption of low waste might not be as valid at this low food price, this study likely significantly underestimated the 
expenditure on stored food by ignoring the use of net worth. Therefore the reduction in expenditure is, if anything, conservative.

At $\$ 8 / \mathrm{kg}, \$ 25 / \mathrm{kg}$, and even $\$ 80 / \mathrm{kg}$, many lives could be saved, and the probability of the collapse of civilization would be significantly reduced. These prices could be encountered if alternate foods with current higher prices are required, or if the current low price alternate foods become much more expensive during a catastrophe.

\section{Discussion}

There is the concern that a backup plan from alternate foods will mean that humanity will work less hard to prevent catastrophes, called "moral hazard." However, prevention is still the preferable outcome. And in some cases humanity has little ability to prevent the catastrophes, such as with a supervolcanic eruption (though some have suggested that it may be possible to prevent a supervolcanic eruption (Denkenberger and Blair, 2017)).

As expected, animal products are generally more expensive than plant foods. The conversion of fossil fuel to food is far more efficient in the case of methane-digesting bacteria than with artificial light and photosynthesis, which is why the methane digesting bacteria are much less expensive. Industrial processes generally produce low-price food.

Despite significant costs associated with producing alternate foods and the fact that more people are fed, total expenditure on food actually falls due to producing alternate foods (see Figure 1). This can be understood knowing that the demand for food in a catastrophe is inelastic (meaning that a $1 \%$ reduction in quantity supplied results in a price increase of more than $1 \%$ ). In this case, the inelasticity comes from very high income inequality. Previous work has shown that investment in preparation for alternate food production is a very cost-effective way of saving lives. The present analysis shows that even if one were not motivated by saving lives, but instead simply reducing food expenditure, investment in alternate food preparation would be beneficial. The most expensive type of preparations considered in previous work was training at about $\$ 30$ billion over 10 years. The probability that the sun will be blocked is order of magnitude $1 \%$ in 10 years (Denkenberger and Pearce, 2015). While it is not clear exactly what food price will result from preparations, if it were $\$ 8 / \mathrm{kg}$, this would save $\sim \$ 50$ trillion in a catastrophe. Even multiplying by the $1 \%$ probability that the catastrophe occurs, the benefit would still be $\$ 500$ billion, which is $\$ 470$ billion more than the total of the most expensive preparations. Because a 10 year window is considered, the interest on the investment would be relatively small. The preparations of planning, research and development would be orders of magnitude less expensive than training. Though these preparations would not have quite as high probability of success, they would still be even more cost effective. Looking specifically at the rich people who would survive even with only food storage, the reduction in their expenditure would be even larger. So this means the investment in preparation could be justified selfishly by people with greater than about $\$ 20,000$ per person per year income (the relatively wealthy from a global perspective).

Because investment in alternate foods can now be seen as a monetary investment, it could make sense for companies as well. If expenditure on stored food is extremely high and many people die, the market for other goods will plummet. Disregarding public relations benefits, only large companies could see a positive monetary return associated with investing in alternate foods

preparations if the only benefit were a reduction in the fall in demand for their products and services. However, certain companies would be well positioned to help in the effort of producing 
alternate foods. These include chemical companies who could produce methane-digesting bacteria and cellulosic sugar. It could also include shipping companies because much more material might need to be moved to produce alternate foods. And it could include manufacturing companies that could retrofit their factories to produce products such as more freight vehicles and wood chippers. Furthermore, it could include food processing companies that could be retrofitted to extract calories from leaves. Livestock companies would also be important. Fishing and seed companies would also be key in the likely scenario that the sun is not blocked completely. Even if these companies are small, internal preparations for how to transition to the production of goods and services relevant to alternate foods could be a good monetary investment. If there are present time benefits associated with alternate foods, this could further broaden the number of companies that could make a monetary return doing work relevant to alternate foods while increasing the survival rates of humanity during a global catastrophe.

In the case of stored food only (the worst survival scenario), income inequality is desirable from a highest number of survivors perspective. This is because the poor can afford very little food, so little is "wasted" on people who will die anyway. If there were no income inequality, everyone would have equal access to the food, and then everyone would starve to death. In stark contrast, if the price of alternate food is moderate, income inequality is a negative. This is because everyone could survive if they had enough money to afford the food. Given how beneficial alternate foods preparations are, it is hoped that preparation is the more likely scenario, so efforts to reduce income inequality that are better for society during normal times (Wilkinson and Pickett, 2011) will bolster global population survival in the event of a global catastrophe that greatly reduces or terminates conventional agricultural production for several years.

Finally, alternate foods could also be used to prevent species from going extinct due to the sun blocking catastrophe (Baum et al., 2016). The lower the price of alternate foods, the more feasible this becomes.

\section{Conclusions}

\subsection{Future work}

This study provides an important first estimate of alternative food prices. Important future work includes finding a viable mechanism for the funding of alternate foods research and scale-up planning. Other research has shown that these preparations could be in the selfish interest of an individual country (the U.S.) (Denkenberger and Pearce, 2017). The present work shows that preparations could be in the selfish interest of the global rich (i.e. those with per person incomes higher than $\$ 20,000 /$ year), possibly within a single country for lower cost preparations. A mechanism for coordination among these many stakeholders other than governments is future work. Since preparation for alternate foods is much less expensive than storing more food (Baum et al., 2015), this non-government option would be less expensive than the individuals storing food.

Additional future work is needed to generate more accurate estimates of the price of alternate foods during a catastrophe, with priority for the lower current price ones including leaf extract, fish and Tibetan grains. It would be useful to examine prices in past famines. A simple estimation method would be scaling current price of food upward by a constant factor. The following methods would incrementally improve on this first approximation: 1) scaling current 
price of food upward based on how much increase from current food production would be required; 2) quantifying some inputs like transportation and feedstock at current prices; 3) including the feasibility and cost of retrofitting equipment; 4) using an economic input output model that adjusts prices for inputs such as water, rent, capital markets and energy. High accuracy would be using a general equilibrium model that adjusts prices for inputs. And the highest accuracy would be using a general equilibrium model as a function of time. These advanced interactive models could include consumer preferences for different types of food.

\subsection{Conclusion}

The blocking of the sun could be caused by nuclear winter or other catastrophes, and it has significant probability. At the current state of preparation, the collapse of civilization is likely, and civilization might not recover, harming many future generations (Beckstead, 2013). Previous work has shown that alternate foods not dependent on sunlight could feed everyone if the sun is blocked and preparation for alternate foods is a highly cost-effective way of saving lives. This meant that preparation makes sense for organizations/individuals who value saving lives, such as United Nations affiliates, international aid and development government programs and nongovernmental organizations, government programs targeted only at their own citizens, etc. The present work is the first to estimate the price of the alternate foods during such a catastrophe. First the present price of alternate foods is estimated and this provides some indication of the price of the foods during a catastrophe. A catastrophe scenario is considered with global trade and information sharing, but no migration, loans, aid or conflict. For a catastrophe that disabled agriculture for five years, the results show that only about $10 \%$ of the population would survive in this scenario. Assuming that the people only use present income to afford the food, the price of dry food would rise to approximately $\$ 100 / \mathrm{kg}$. The expenditure on this food would be approximately $\$ 90$ trillion over five years. However, if sufficient alternate food could be produced at $\$ 8 / \mathrm{kg}$, $69 \%$ of people would survive, saving over 4 billion lives. The loss of civilization and its impact on many future generations would be much lower probability in this scenario. Even though so many more people would survive, the price of the food would be so much lower that the total expenditure on food would be approximately $\$ 50$ trillion less. This means that investments in preparing for alternate foods would be cost effective simply monetarily, not counting saved lives. Given the significant risk of nuclear winter, this would likely be a good investment for rich people for themselves, even though they would survive with stored food only. A non-governmental mechanism of coordinating these rich people may be possible. However, even easier would be finding companies which have their best interests aligned with alternate foods preparations. Since these investments pay back monetarily, they would save lives at negative cost. Therefore, outreach to companies is high priority.

\section{Acknowledgements}

The authors would like to acknowledge helpful discussions with Steven Greidinger and Dave Kennedy. The views in this paper are the authors' and are not necessarily the views of the Global Catastrophic Risk Institute nor the Alliance to Feed the Earth in Disasters. This study received a small amount of funding from ALLFED. 


\section{References}

Bank, W. (2017), GDP Growth, World Bank.

Baum, S.D., Denkenberger, D.C. and Pearce, J.M. (2016), "Alternative Foods as a Solution to Global Food Supply Catastrophes", Solutions.

Baum, S.D., Denkenberger, D.C., Pearce, J.M., Robock, A. and Winkler, R. (2015), "Resilience to global food supply catastrophes", Environment Systems and Decisions, pp. 1-13.

Beckstead, N. (2013), "On the overwhelming importance of shaping the far future", Rutgers University.

Bostrom, N. (2003), “Astronomical Waste: The Opportunity Cost of Delayed Technological Development”, Utilitas, Vol. 15 No. 3, pp. 308-314.

Bostrom, N. and Cirkovic, M.M. (Eds.). (2008), Global Catastrophic Risks, Oxford University Press, New York.

Coates, J.F. (2009), "Risks and threats to civilization, humankind, and the earth", Futures, Vol. 41 No. 10, pp. 694-705.

Denkenberger, D. and Blair, R. (2017), "Interventions that May Prevent or Mollify Supervolcanic Eruptions", Futures, Vol. Forthcoming.

Denkenberger, D. and Pearce, J.M. (2014), Feeding Everyone No Matter What: Managing Food Security After Global Catastrophe, Academic Press.

Denkenberger, D.C., Cole, D.D., Abdelkhaliq, M., Griswold, M., Hundley, A.B. and Pearce, J.M. (2017), "Feeding Everyone if the Sun is Obscured and Industry is Disabled", International Journal of Disaster Risk Reduction, Vol. 21, pp. 284-290.

Denkenberger, D.C. and Pearce, J.M. (2015), "Feeding everyone: Solving the food crisis in event of global catastrophes that kill crops or obscure the sun", Futures, Vol. 72, pp. 57-68.

Denkenberger, D.C. and Pearce, J.M. (2016), “Cost-Effectiveness of Interventions for Alternate Food to Address Agricultural Catastrophes Globally", International Journal of Disaster Risk Science, Vol. 7 No. 3, pp. 205-215. 
Denkenberger, D.C. and Pearce, J.M. (2017), “Cost-Effectiveness of Interventions for Alternate Food in the US to Address Agricultural Catastrophes", International Journal of Disaster Risk Reduction.

Do, T., Anderson, K. and Brorsen, B.W. (2010), “The World’s wheat supply”, Oklahoma Cooperative Extension Service.

Griswold, M., Denkenberger, D., Abdelkhaliq, M., Cole, D., Pearce, J. and Taylor, A.R. (2016), "Vitamins in Agricultural Catastrophes", Proceedings of the 6th International Disaster and Risk Conference, presented at the 6th International Disaster and Risk Conference, Davos, Switzerland.

Hahn, W. (2017), Choice Beef Values and Spreads and the All-Fresh Retail Value, United States Department of Agriculture.

Humbird, D., Davis, R., Tao, L., Kinchin, C., Hsu, D., Aden, A., Schoen, P., et al. (2011), Process Design and Economics for Biochemical Conversion of Lignocellulosic Biomass to Ethanol: Dilute-Acid Pretreatment and Enzymatic Hydrolysis of Corn Stover, National Renewable Energy Laboratory (NREL), Golden, CO.

Hurburgh, C. (2006), "Moisture Basis Conversions for Grain Composition Data", Agriculture and Environment Extension Publications, available at: http://lib.dr.iastate.edu/extension_ag_pubs/135.

Kennedy, D. and Leaf for Life. (1993), Leaf Concentrate: A Field Guide for Small-Scale Programs.

Kochhar, R. (2015), A Global Middle Class Is More Promise than Reality, LIS Working Paper Series.

Kouřimská, L. and Adámková, A. (2016), "Nutritional and sensory quality of edible insects", NFS Journal, Vol. 4, pp. 22-26.

Kummu, M., Moel, H. de, Porkka, M., Siebert, S., Varis, O. and Ward, P.J. (2012), "Lost food, wasted resources: Global food supply chain losses and their impacts on freshwater, cropland, and fertiliser use", Sci. Total Environ., Vol. 438, pp. 477-489. 
Leaf for Life. (2013), “Industrial leaf concentrate process (France)", available at: http://www.leafforlife.org/pages/industri.htm.

Maher, T.M. and Baum, S.D. (2013), "Adaptation to and recovery from global catastrophe", Sustainability, Vol. 5 No. 4, pp. 1461-1479.

Meadows, D.H., Randers, J. and Meadows, D.L. (2004), Limits to Growth: The 30 Year Update, Chelsea Green Publishing Company, White River Junction, VT.

Milanovic, B. (n.d.). "Global Income Inequality by the Numbers: in History and Now. An Overview, 2012".

Myer, M.A., Paget, M.L. and Lingard, R.D. (2009), Performance of T12 and T8 Fluorescent Lamps and Troffers and LED Linear Replacement Lamps, Pacific Northwest National Laboratory, prepared for the U.S. Department of Energy.

OPEF. (2017), “Combating Malnutrition with Leaf Concentrate”, available at: http://nutritionluzerne.org/en/.

Robock, A., Oman, L. and Stenchikov, G.L. (2007), "Nuclear winter revisited with a modern climate model and current nuclear arsenals: Still catastrophic consequences", J. Geophys. Res. Atmos., Vol. 112 No. D13, pp. 1984-2012.

Roslev, P., Iversen, N. and Henriksen, K. (1997), “Oxidation and assimilation of atmospheric methane by soil methane oxidizers", Appl. Environ. Microbiol., Vol. 63 No. 3, pp. 874880.

Shultz, G.P., Perry, W.J., Kissinger, H.A. and Nunn, S. (2007), “A world free of nuclear weapons", Wall Street Journal, Vol. 4 No. 01, p. 2007.

Smith, P.E. (1985), "Year-class strength and survival of O-group clupeoids", Can. J. Fish. Aquat.Sci., Vol. 42 No. S1, pp. s69-s82.

Spinosa, R. (2008), "Fungi and sustainability”, Fungi, Vol. 1 No. 1.

Tilman, D., Cassman, K.G., Matson, P.A., Naylor, R. and Polasky, S. (2002), “Agricultural sustainability and intensive production practices", Nature, Vol. 418 No. 6898, pp. 671677. 
Unibio. (2014), “What Is Uniprotein ${ }^{\circledR}$ ?”, available at: http://www.unibio.dk/?page_id=47. United States Department of Agriculture. (2006), USDA National Nutrient Database for Standard Reference Release 17.

“United States Natural Gas Industrial Price”. (2017), Www.eia.gov, 28 April, available at: https://www.eia.gov/dnav/ng/hist/n3035us3a.htm (accessed 15 May 2017).

USDA. (2015), Flour, White, All Purpose, U.S. Department of Agriculture.

USDA. (2016), USDA National Nutrient Database for Standard Reference Release 28, available at: https://ndb.nal.usda.gov/ndb/foods/show/6622?fgcd=\&manu=\&lfacet=\&format=\&count $=\& \max =50 \&$ offset $=\&$ sort $=$ default \&order $=$ asc \&qlookup $=$ white + flour $\& d s=\& q t=\& q p=\& q$ $\mathrm{a}=\& \mathrm{qn}=\& \mathrm{q}=\& \operatorname{ing}=($ accessed 15 May 2017).

USDA. (2017a), Agricultural Marketing ServiceLivestock, Poultry \& Grain Market News, U.S. Department of Agriculture.

USDA. (2017b), "Food Composition Databases Show Foods List”, USDA Food Composition Databases, Database, , 29 March, available at: https://ndb.nal.usda.gov/ndb/search/list (accessed 13 May 2017).

USDA. (2017c), Egg Market News Report, No. 1520-6122, United States Department of Agriculture, p. 3.

USDA. (2017d), USDA Weekly National Whole Broiler/Fryer Report, United States Department of Agriculture, available at: www.ams.usda.gov/market-news/livestock-poultry-grain.

USDA. (2017e), Mushrooms, United States Department of Agriculture, available at: http://usda.mannlib.cornell.edu/usda/current/Mush/Mush-08-19-2016.pdf.

Warren, L. (2017), Announcement of Advanced Prices and Pricing Factors, United States Department of Agriculture, p. 5.

"Wholesale Mealworm Larvae". (n.d.). Alibaba, available at: //www.alibaba.com/productdetail/china-larvae-fish-foods-mealworm_60417084614.html (accessed 14 May 2017). 
“Wholesale Sardines". (n.d.). Alibaba, available at: //www.alibaba.com/product-detail/NewProducts-Whole-Frozen-Saradine-Fish_60633494124.html (accessed 13 May 2017).

Wijffels, R.H. and Barbosa, M.J. (2010), “An outlook on microalgal biofuels”, Sci., Vol. 329, pp. 796-799.

Wilkinson, R. and Pickett, K. (2011), The Spirit Level: Why Greater Equality Makes Societies Stronger, Bloomsbury Publishing USA.

Yardeni, E., Johnson, D. and Quintana, M. (2017), Global Economic Briefing: Global Inflation, Yardeni Research, p. 18. 